\title{
The ACE-2 in COVID-19: Foe or Friend?
}

Authors

Rinkoo Dalan 1, 2, Stefan R. Bornstein'2, 3, 4, 5, Ali El-Armouche6, Roman N Rodionov7, Alexander Markov , Ben Wielockx Felix Beuschlein ${ }^{5,10}$, Bernhard 0. Boehm1, 2

Affiliations

1 Tan Tock Seng Hospital, Singapore

2 Lee Kong Chian School of Medicine, Nanyang Technological University Singapore, Singapore

3 Department of Medicine III, University Hospital Carl Gustav Carus, Dresden, Germany

4 Division of Diabetes \& Nutritional Sciences, Faculty of Life Sciences \& Medicine, King's College London, London, UK

5 Klinik für Endokrinologie, Diabetologie und Klinische Ernährung, University Hospital, Zürich, Switzerland

6 Department of Pharmacology and Toxicology, Medical Faculty Carl Gustav Carus, Technische Universität Dresden, Dresden, Germany

7 Division of Angiology, Department of Internal Medicine III, University Hospital Carl Gustav Carus, Technische Universität Dresden, Dresden, Germany

8 Department of General Physiology, Saint-Petersburg State University, Saint-Petersburg, Russia

9 Institute of Clinical Chemistry, University Hospital Carl Gustav Carus, Technische Universität Dresden, Dresden, Germany

10 Medizinische Klinik und Poliklinik IV, Klinikum der Universität München, Munich, Germany

Key words

COVID-19, ACE-2, renin angiotensin system

received $\quad 06.04 .2020$

accepted $\quad 07.04 .2020$

Bibliography

DOI https://doi.org/10.1055/a-1155-0501

Published online: 27.4.2020

Horm Metab Res 2020; 52: 257-263

(C) Georg Thieme Verlag KG Stuttgart · New York

ISSN 0018-5043

Correspondence

Prof. Bernhard O. Boehm, MD, FRCP (London)

Ong Tiong Tat Chair Professor of Diabetes Research

Professor of Metabolic Medicine

Lee Kong Chian School of Medicine

Singapore

bernhard.boehm@ntu.edu.sg

\section{ABSTRACT}

COVID-19 is a rapidly spreading outbreak globally. Emerging evidence demonstrates that older individuals and people with underlying metabolic conditions of diabetes mellitus, hypertension, and hyperlipidemia are at higher risk of morbidity and mortality. The SARS-CoV-2 infects humans through the angiotensin converting enzyme (ACE-2) receptor. The ACE-2 receptor is a part of the dual system renin-angiotensin-system (RAS) consisting of ACE-Ang-II-AT ${ }_{1}$ R axis and ACE-2-Ang-(1-7)-Mas axis. In metabolic disorders and with increased age, it is known that there is an upregulation of ACE-Ang-II-AT ${ }_{1} \mathrm{R}$ axis with a downregulation of ACE-2-Ang-(1-7)-Mas axis. The activated ACE-Ang-II-AT1R axis leads to pro-inflammatory and pro-fibrotic effects in respiratory system, vascular dysfunction, myocardial fibrosis, nephropathy, and insulin secretory defects with increased insulin resistance. On the other hand, the ACE-2-Ang(1-7)-Mas axis has anti-inflammatory and antifibrotic effects on the respiratory system and anti-inflammatory, antioxidative stress, and protective effects on vascular function, protects against myocardial fibrosis, nephropathy, pancreatitis, and insulin resistance. In effect, the balance between these two axes may determine the prognosis. The already strained ACE2-Ang-(1-7)-Mas in metabolic disorders is further stressed due to the use of the ACE- 2 by the virus for entry, which affects the prognosis in terms of respiratory compromise. Further evidence needs to be gathered on whether modulation of the renin angiotensin system would be advantageous due to upregulation of Mas activation or harmful due to the concomitant ACE-2 receptor upregulation in the acute management of COVID-19.
ABBREVIATIONS
ACE Angiotensin converting enzyme
Ang Angiotensin
ARDS Acute respiratory distress syndrome
$\mathrm{AT}_{1} \mathrm{R}$ Angiotensin 1 receptor
RAS Renin angiotensin system
SARS Severe acute respiratory syndrome 


\section{Introduction}

Coronaviruses (CoV) are a large family of viruses that cause illness ranging from the common cold to more severe diseases such as Middle East Respiratory Syndrome (MERS-CoV) and Severe Acute Respiratory Syndrome (SARS)-CoV. The SARS-CoV-2, has caused a rapidly spreading outbreak (COVID-19) with over 300000 infected cases and more than 13000 deaths globally [1-8], (https://coronavirus.jhu.edu/map.html). The SARS-CoV-2, a positive strand RNA virus, has been seen to infect humans through the angiotensin converting enzyme -2 (ACE-2) receptor [9].

In COVID-19 infections, emerging evidence demonstrates that older individuals and people with underlying metabolic conditions of diabetes mellitus, hypertension, and hyperlipidemia are at higher risk of morbidity and mortality [1-8].

In individuals with hypertension, diabetes, and other cardiovascular disorders with vascular complications, the renin angiotensin system (RAS) is known to be activated with an increase in ACE activity and a downregulation of ACE-2. Modulation of this system by ACE-inhibitors or $\mathrm{AT}_{1}$-Receptor blockers is now considered as the first-line therapy as well as for prevention and management of vascular complications.

In this regard, the questions arise if (i) differences in ACE-2 may explain the exacerbated course of disease in patients with metabolic diseases and (ii) if ACE modulation in COVID-19 patients is neutral, beneficial, or harmful. The latter question may have immediate therapeutic consequences for millions of patients. Moreover, ACE-2-based therapy has been proposed as a potential therapeutic approach in COVID-19 pneumonia [10].

\section{The ACE-2 enzyme and infection with SARS-CoV}

The angiotensin converting enzyme 2 (ACE-2), a single pass type 1 membrane monocarboxypeptidase, discovered 2 decades ago [11] consists of an $\mathrm{N}$-terminal peptidase domain and C-terminal collectrin like domain [9]. It is the peptidase domain that is responsible for the main functions of the renin angiotensin system (RAS) [9]. The ACE- 2 shares $40 \%$ homology with the $\mathrm{N}$-terminal catalytic domain of ACE, and a hydrophobic region near the C-terminus likely to serve as a membrane anchor $[9,11]$. The ACE-2 protein is encoded by the ACE- 2 gene located on chromosome Xp22. These ACE-2 proteins are more abundantly expressed on the apical surface of the well-differentiated and mostly ciliated airway epithelium of the lungs (alveolar Type- 2 cells), and enterocytes of the small intestine [12]. Furthermore, ACE-2 protein is expressed in arterial and venous endothelial cells and arterial smooth muscle cells, in the heart, kidneys, adrenal glands, pancreas, skeletal muscle, and adipose tissues [11].

The coronavirus SARS-CoV-2, a single stranded RNA virus, has been seen to infect humans through their envelope spike glycoprotein (S-protein), which is responsible for CoV cell entry and hostto-host transmission. During viral infection, this $S$-protein cleaves into S1 and S2 [9]. The FURIN cleavage site in the SARS-CoV-2S protein may provide a priming mechanism [13]. The ectodomain S1 binds to the peptidase domain of the ACE-2 enzyme, while the 52 is cleaved further by the host cell serine protease TMPRSS2 [14] resulting in membrane fusion. Both these steps are essential for the viral entry into the cells.
An in vivo study shows that the infection of human airway epithelia by SARS coronavirus correlated with the state of cell differentiation and ACE-2 expression and localization [15]. The infection tends to occur more readily through well differentiated ciliated cells with higher ACE-2 expression [15]. It has been observed that ACE-2 membrane expression and plasma levels are reduced after infection with SARS coronavirus [16]. Further, SARS CoV spike protein has been found to reduce ACE-2 expression and to augment pulmonary injury [16]. However, treatment with blockers of the renin-angiotensin system reduced the pulmonary injury by activating the ACE-2-Ang-(1-7)-Mas axis.

\section{The Renin-angiotensin system}

In the classical endocrine model of the RAS, renin cleaves its substrate, angiotensinogen (AGT), to produce the inactive peptide, angiotensin I (Ang I), which is then converted to angiotensin II (Ang II) by endothelial angiotensin-converting enzyme (ACE). The catalytic activity of ACE to activate Ang II occurs most extensively in the lung. Ang II mediates vasoconstriction as well as aldosterone release from the adrenal gland, resulting in sodium retention and an increase in blood pressure through the angiotensin 1 receptor $\left(\mathrm{AT}_{1} \mathrm{R}\right)$.

However, recent evidence suggests that RAS also includes local systems with autocrine (cell-to-same cell) and paracrine (cell-to-different cell) effects in addition to the classical circulating RAS with its well-known classical endocrine effects. In particular, Ang II generation at the tissue level by the tissue specific RAS appears to have physiologic effects that are as important as circulating/systemic Ang II and, under some circumstances, more important than circulating Ang II. Therefore, the RAS system is not only involved in controlling blood volume and blood pressure but with the tissue specific local systems it directs tissue remodeling, endothelial dysfunction, and fibrosis [17-20].

Simplistically, it can be seen as a dual function system, which acts through two apparently opposite arms: the one responsible for the main actions of this system is constituted by the ACE Ang II-AT 1 receptor axis and the other, a counterregulatory arm, is formed by the ACE-2-Ang-(1-7)-Mas axis. The catalytic activity of ACE results in increased Ang II levels and increased catabolism of Ang-(1-7) whereas the catalytic activity of ACE-2 is predominantly on Ang I and Ang II and leads to formation of Ang-(1-7). Ang-(17) acts on the G-protein coupled receptor Mas and is known to have counterregulatory actions on Ang II resulting in vasoconstriction and growth inhibitory effects [17-20] (See - Fig. 1).

\section{The Renin-angiotensin system in metabolic disorders}

A common mechanism by which diabetes, hypertension, and other metabolic disorders cause vascular complications is endothelial dysfunction, inflammation, and atherosclerosis. In these disorders, the ACE-Ang II-AT 1 receptor axis is activated with a downregulation of ACE-2-Ang-(1-7)-Mas axis [19-21], which leads to increased local and circulatory Ang II with a decrease in Ang-(1-7) and subsequent increased oxidative stress, activation of the endothelium, smooth muscle cell migration, growth, proliferation and thrombosis [19-21]. Deficiency in ACE-2 leads to increased formation of atherosclerotic plaques and blocking of ACE- 2 results in prevention of atherosclerosis [20] ( $\mathbf{F i g} \mathbf{1}$ ). ACE-2 is present in multiple 


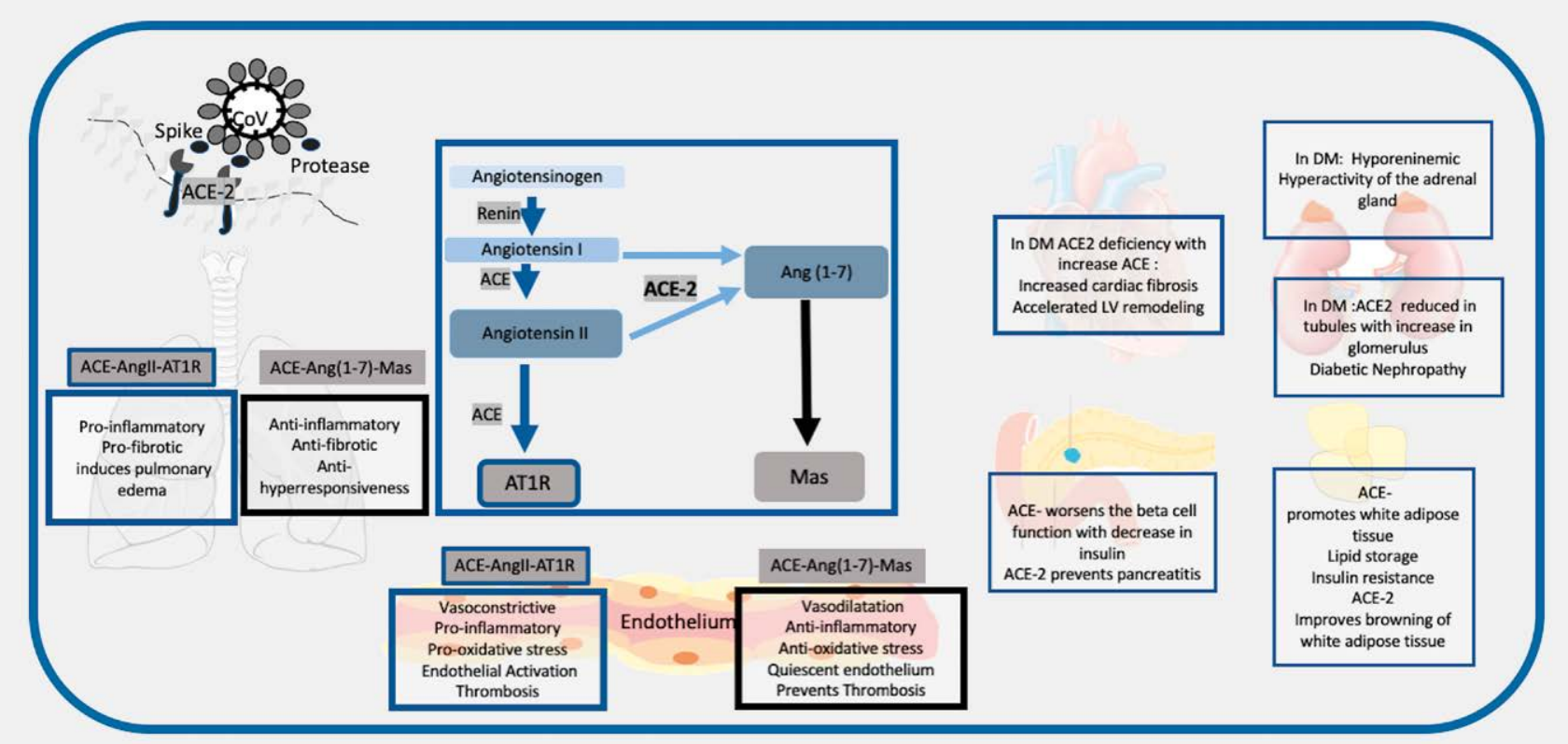

- Fig. 1 Schematic Representation to show the renin angiotensin system in diabetes and the interaction of the SARS-CoV 2 with the ACE-2. 1. The SARS-CoV 2 interacts with the ACE- 2 through the spike proteins after priming by tissue serene proteases. It uses the ACE- 2 protein to enter the alveolar cells in the lungs. 2 . The renin angiotensin system consists of renin which catalyzes the conversion of angiotensinogen to angiotensin 1 (Ang 1 ). The subsequent axis depends on the balance between the Angiotensin converting enzyme (ACE) and ACE-2. ACE converts Ang 1 to Ang II and this acts in the angiotensin receptor $\left(A T_{1} R\right)$, whereas ACE- 2 converts it to Ang-(1-7), which acts on the Mas receptor. 3 . In the respiratory system activation of ACE leads to a proinflammatory, pro-fibrotic , pro-hyperresponsiveness response in the respiratory system, whereas ACE-2-Ang-(1-7)-Mas induces a protective mechanism of anti-inflammatory, anti-fibrotic and anti-hyperresponsiveness. A lower ACE-2 will put these individuals at higher risk of respiratory distress. 4 . In hypertension, diabetes, and CVD, the ACE related pathway is activated with downregulation of the ACE- 2 pathway. These results in the multi-organ complications seen in metabolic diseases with endothelial dysfunction promoting atherosclerosis, increased cardiac fibrosis and LV remodeling, diabetic nephropathy, hyperactivity of adrenal gland, and it decreases insulin release and increases insulin resistance.

5. Infection with COVID-19 may exacerbate the ACE-2 deficiency in these patients in all organs and maybe responsible for the multiorgan failure.

organs and has various functions. In the heart, ACE-2 prevents progressive cardiac fibrosis associated with aging and/or cardiac pressure overload and is beneficial in heart failure $[19,20]$. In most forms of chronic kidney disease including diabetic and hypertensive nephropathy, expression of ACE-2 has been reported to be reduced in kidney tubules with an increased expression in the glomerula [20]. This imbalance has been postulated as a potential cause of diabetic nephropathy.

In the adrenal glands, the local secretory RAS stimulates aldosterone production and serves as an amplification system for circulating Ang II. Importantly the regulation of the secretory adrenal RAS is independent of the circulatory RAS and the activity of the adrenal RAS correlates with aldosterone production and regulation of potassium serum concentrations [22]. Severe diabetes has been associated with hyporeninaemic hyperactivity of the adrenal gland [23].

In the pancreas, the ACE-2-Ang-(1-7)-Mas axis has been described to protect the function of insulin-producing beta cells by improving the function of islet microvascular endothelial cells. Further, activation of endothelial nitric oxide synthase and NO signaling pathways via the ACE-2-Ang-(1-7)-Mas axis may have anti-inflammatory beneficial effects in pancreatitis $[23,24]$. In the skeletal muscle, the ACE-2-Ang-(1-7)-Mas axis has been described to decrease insulin resistance [25]. ACE-2 may exert potential anti-obesity effects via stimulating brown adipose tissue formation and induction of browning in white adipose tissue [26].

A study done in the survivors of the SARS infections, the organ involvement correlated with the organ expression of ACE-2 with significantly higher immunostaining in the lung, kidney, heart, and islets of pancreas [27]. In this series, 20 of the 39 patients had diabetes during hospitalization, which resolved subsequently suggestive of acute islet cell damage and diabetes, probably due to the use of the ACE-2 receptor domain for viral entry [27].

\section{The renin angiotensin system and the respiratory system}

The respiratory system is a major site of ACE-activity and source of systemic Ang II synthesis. Locally produced Ang II may trigger increasing vascular permeability facilitating pulmonary edema. The ACE-2-Ang-(1-7)-Mas axis that is highly expressed in the lungs, may potentially induce pulmonary vasoconstriction in response to hypoxia, which is an important process in preventing shunting in patients with pneumonia or lung injury [19]. In acute respiratory distress syndrome (ARDS) mouse models, ACE-2 knockout mice displayed more severe ARDS symptoms compared with wildtype mice, while overexpression of ACE-2 appeared to be protective [19]. 
Thus, stimulation of the ACE-2-Ang-(1-7)-Mas axis may have anti-inflammatory and antifibrotic effects in the pulmonary system, and these actions could potentially be favorable in the recovery of patients with pulmonary inflammation. It is possible that an ACE/ ACE-2 imbalance is one of the potential mechanisms explaining why patients with cardio-metabolic problems are at higher risk for respiratory failure [20].

In an animal model study, it has been reported that infusion of SARS CoV spike protein reduced ACE-2 expression and augmented pulmonary injury. However, treatment with blockers of the renin-angiotensin system reduced the pulmonary injury by activating the ACE-2-Ang-(1-7)-Mas axis [16]. Therefore, it may be assumed that the inherent downregulation of the ACE-2-Ang-(1-7)Mas axis (as seen in metabolic conditions) is exacerbated in the COVID-19 state because (i) the virus uses the peptidase domain of the enzyme for entry into the cells and (ii) there is a decrease in ACE-2 with an increase in ACE [9].

\section{Pathological features of COVID-19 infection}

In COVID-19 infections, chest radiography typically shows patchy or diffuse asymmetric airspace opacities bilaterally more in the peripheral zones and in later stages ground glass opacities. CT Scan typically shows bilateral involvement, which is different from SARS and MERS which starts unilaterally. Moreover, it shows bilateral multifocal ground-glass opacities with a peripheral lung involvement in milder cases with more widespread consolidation in patients who go to the intensive care unit. Pleural effusion, cavitation, pulmonary nodules, and lymphadenopathy have not been reported in patients with COVID-19. An important clinical observation of COVID-19 infection in China was that some individuals with early infection exhibited no symptoms. Interestingly, they even had negative swab results (due to absence of infection in the upper respiratory tract) and normal chest X-rays, however, showed significant changes in the CT scan of the lungs [28].

Histopathological examination of early COVID-19 infected lungs, which were serendipitously detected in specimens operated for lung cancer, revealed exudative and proliferative phases of acute lung injury, edema and congestion of alveolar septa with inflammatory infiltrates (macrophages), type II pneumocytes hyperplasia with viral inclusions, organization of inflammatory exudates and interstitial fibrosis [29]. These pathological findings corroborated with the $\mathrm{CT}$ findings of patchy ground glass opacities. Intriguingly, these pathological findings of inflammatory and fibrotic changes are known to be exacerbated in animal models of ACE-2 knockout mice [19].

Histopathological examination from autopsies of individuals who have succumbed from COVID-19 infections showed degenerated and necrotized cells in the myocardium and blood vessels with interstitial inflammatory infiltrates and focal necrosis. In the kidneys, proteinaceous exudates in the bowman's capsule surrounding the glomerulus, degeneration and shedding of the renal tubular epithelial cells and hyaline casts, microthrombi and fibrotic foci have been reported [30,31]. Some of these changes of myocardial fibrosis and renal changes are already seen in the chronic phase of metabolic disorders due to ACE-2 downregulation and these may get exacerbated $[19,20]$.

\section{Observations from clinical presentation and course of COVID-19 infections}

The vast majority of COVID-19 patients have mild symptoms. However, a significant percentage is critically ill with admission to an intensive care unit (ICU, approx. $10 \%$ ) with $4 \%$ case fatality rate globally (John Hopkins Coronavirus Resource Center: https://coronavirus.jhu.edu/). Mortality is higher in patients with underlying hypertension, type-2 diabetes mellitus, or cardiovascular disease [1-3]. To address this further, we performed a cumulative analysis of published data from China and South Korea, which showed that a disproportionately higher percentage of patients with a higher morbidity (requiring ICU care, ARDS) had hypertension (28\%), type-2 diabetes (17\%), CVD (8\%) as an underlying disease. Moreover, patients admitted to the ICU had a higher systolic BP when compared to asymptomatic cases [4-7] and in a recent series reported none of the nonsurvivors had hypotension [3] ( A limitation of the data summarized in $>$ Table $\mathbf{1}$ is the posibility that some cases were reported twice in different series. Interestingly, however, in a recent case report on a mild case extensively followed in Australia, a low level of the monocyte chemoattractant protein-1 (MCP-1), a key biomarker of type-2 diabetes related vascular complications, was found to be associated with minor disease pathology [32]. In a recent preprint study, hypokalemia due to renal potassium wasting has been reported with $93 \%$ of the critically ill patients having hypokalemia independent of gastrointestinal symptoms [33].

The presence of higher expression of ACE-2 receptors or its upregulation although initially thought to be a risk factor for infection is unlikely the case. In a recent preprint study, wherein they integrated public genomics, epigenomics, and transcriptomics data, they found that the expression of ACE-2 is relatively high in Asian females and young people while it is lower in males, and further decreases with age and with the progression of type-2 diabetes [34]. This contradicts the hypothesis that higher expression is directly related to increased susceptibility as we know that SARSCov- 2 infections are more common in males and in elderly patients with metabolic disorders.

Taken together, these observations suggest that patients with underlying type-2 diabetes, hypertension and/or cardiovascular diseases are at higher risk for requiring critical care and ventilation. There is evidence that although they are critically ill, they tend to demonstrate normotension to hypertension and hypokalemia, which are classical features of an activated ACE related RAS with a downregulation of the ACE-2 pathway. As per current data, it does not appear that higher ACE-2 expression is associated with an immediate predilection as individuals at risk will tend to have lower ACE-2 expression.

\section{Therapeutic modulations}

Since ACE-2 is the entry receptor for cellular infection by SARS-CoV-2, blocking entry using ACE-2-related therapy could be feasible to prevent the spreading of infection in the lungs and the whole body. Convalescent sera containing neutralizing antibodies against SARS-S protein offer protection against SARS-CoV-2 infection [35]. Therefore, it was suggested to use recombinant human ACE-2 protein to saturate the viral S-protein and thus prevent cellular entry of SARS-Cov-2 [10]. This is especially of interest, since ACE-2 has already been de- 
- Table 1 Mortality (death) and morbidity (ICU stay) associated with cardiometabolic disease based on reported cases in the literature.

\begin{tabular}{|c|c|c|c|c|c|c|}
\hline Reference & Country & Total (n) & Hypertension & Diabetes & CVD & BP \\
\hline $\begin{array}{l}\text { 1. Special Expert Group for Control of } \\
\text { the Epidemic of Novel Coronavirus } \\
\text { Pneumonia of the Chinese Preventive } \\
\text { Medicine Association. Zhonghua Liu } \\
\text { Xing Bing Xue Za Zhi 2020; } 41 \text { : } \\
\text { 139-144 [1] }\end{array}$ & China & $\begin{array}{l}\text { Total: } 45695 \\
\text { Alive: } 44672 \\
\text { Death: } 1023\end{array}$ & $\begin{array}{l}\text { Alive: } 2683 \text { (6\%) } \\
\text { vs. Death: } 161 \\
\text { (15.7\%); } \\
\text { p < } 0.0001^{*}\end{array}$ & $\begin{array}{l}\text { Alive: } 1102(2.5 \%) \\
\text { vs. Death: } 80 \\
\text { ( } 7.8 \%) \\
\text { p < } 0.0001^{*}\end{array}$ & $\begin{array}{l}\text { Alive: } 873(2 \%) \text { vs. } \\
\text { Death: } 92(9 \%) \\
\text { p < } 0.0001^{*}\end{array}$ & - \\
\hline $\begin{array}{l}\text { 2. Korean Society of Infectious } \\
\text { Diseases, Korean Society of Pediatric } \\
\text { Infectious Diseases, Korean Society of } \\
\text { Epidemiology, Korean Society for Anti- } \\
\text { microbial Therapy, Korean Society for } \\
\text { Healthcare-associated Infection } \\
\text { Control and Prevention, Korea Centers } \\
\text { for Disease Control and Prevention. } \\
\text { J Korean Med Sci 2020; 35: e112 [2] }\end{array}$ & South Korea & $\begin{array}{l}\text { Total: } 4212 \\
\text { Death: } 22\end{array}$ & Death: 7 (31\%) & Death: $5(23 \%)$ & Death: 1 (4.5\%) & - \\
\hline $\begin{array}{l}\text { 3. Zhou F et al. Lancet 2020; pii: } \\
\text { S0140-6736(20)30566-3 [3] }\end{array}$ & $\begin{array}{l}\text { Wuhan, } \\
\text { China }\end{array}$ & $\begin{array}{l}\text { Total: } 191 \\
\text { Alive: } 137 \\
\text { Death: } 54\end{array}$ & $\begin{array}{l}\text { Alive: } 32(23.4 \%) \\
\text { vs. Death: } 26 \\
(48 \%) ; p= \\
0.0008^{*}\end{array}$ & $\begin{array}{l}\text { Alive: } 19(13.9 \%) \\
\text { vs. Death: } 17 \\
(31.5 \%) ; p= \\
0.0051^{*}\end{array}$ & $\begin{array}{l}\text { Alive: } 2(1.5 \%) \text { vs. } \\
\text { Death:13 (24.1\%); } \\
p<0.0001^{*}\end{array}$ & - \\
\hline $\begin{array}{l}\text { 4. Huang C et al. Lancet 2020; } 395 \\
\text { (10223): 497-506 [4] }\end{array}$ & China & $\begin{array}{l}\text { Total: } 41 \\
\text { Non-ICU: } 28 \\
\text { ICU: } 13\end{array}$ & $\begin{array}{l}\text { Non-ICU: } 4 \\
\text { (14.3\%) vs. ICU: } 2 \\
(15.3 \%) ; p=0.93\end{array}$ & $\begin{array}{l}\text { Non-ICU: } 7(25 \%) \\
\text { vs. ICU: } 1(7.7 \%) \\
p=0.16\end{array}$ & $\begin{array}{l}\text { Non-ICU: } 3 \\
(10.7 \%) \text { vs. ICU: } 3 \\
(23 \%) ; p=0.32\end{array}$ & $\begin{array}{l}\text { Sys BP: Non-ICU: } \\
145 \text { (123-167) } \\
\text { vs. ICU: } 122 \\
(118-130) ; p= \\
0.018^{*}\end{array}$ \\
\hline $\begin{array}{l}\text { 5. Wang D et al. JAMA 2020; doi: } \\
\text { 10.1001/jama.2020.1585 [5] }\end{array}$ & China & $\begin{array}{l}\text { Total: } 138 \\
\text { Non-ICU: } 102 \\
\text { ICU: } 36\end{array}$ & $\begin{array}{l}\text { Non-ICU: } 22 \\
\text { (21.6\%) vs. ICU: } \\
21(58 \%) ; \\
\text { p <0.001* }\end{array}$ & $\begin{array}{l}\text { Non-ICU: } 6(5.9 \%) \\
\text { vs. ICU: } 8 \text { (22.2\%); } \\
p=0.009\end{array}$ & $\begin{array}{l}\text { Non-ICU: } 11 \\
(10.8 \%) \text { vs. ICU: } 9 \\
(25 \%) ; p=0.001^{*}\end{array}$ & $\begin{array}{l}\text { MAP: Non-ICU: } \\
90 \text { (85-98), vs. } \\
\text { ICU: } 91 \text { (78-96); } \\
p=0.33\end{array}$ \\
\hline $\begin{array}{l}\text { 6. Guan W J et al. NEJM 2020; doi: } \\
\text { 10.1056/NEJMoa2002032 [6] }\end{array}$ & China & $\begin{array}{l}\text { Total: } 1099 \\
\text { Non-Severe: } \\
926 \\
\text { Severe: } 173\end{array}$ & $\begin{array}{l}\text { Non-severe: } 124 \\
\text { (13.4\%) vs. } \\
\text { Severe: } 41 \\
(23.7 \%) \\
\text { p < } 0.001^{*}\end{array}$ & $\begin{array}{l}\text { Non-severe: } 53 \\
\text { (5.7\%) vs. Severe: } \\
28(16.2 \%) ; \\
\text { p < } 0.001^{*}\end{array}$ & $\begin{array}{l}\text { Non-severe: } 17 \\
(1.8 \%) \text { vs. Severe: } \\
10(5.8 \%) ; \\
p<0.001^{*}\end{array}$ & \\
\hline $\begin{array}{l}\text { 7. Wu C et al. JAMA Intern Med 2020; } \\
\text { doi: 10.1001/jamainternmed.2020.0994 } \\
\text { [7] }\end{array}$ & China & $\begin{array}{l}\text { Total : } 201 \\
\text { Non ARDS: } \\
117 \\
\text { ARDS : } 84\end{array}$ & $\begin{array}{l}\text { Non-ARDS: } 16 \\
\text { (13.7\%) vs. ARDS: } \\
23(27.4 \%) ; p= \\
0.02\end{array}$ & $\begin{array}{l}\text { Non-ARDS: } 6 \\
\text { (5.1\%) vs. ARDS: } \\
16(19 \%) ; p= \\
0.002\end{array}$ & $\begin{array}{l}\text { Non-ARDS: } 3(2.6) \\
\text { vs. ARDS: } 5(6 \%) \\
p=0.40\end{array}$ & \\
\hline $\begin{array}{l}\text { Consolidated chi-square test for } \\
\text { patients reported in references } 4-7 \\
\text { above [4-7] }\end{array}$ & China & $\begin{array}{l}\text { Total: } 1479 \\
\text { Non-severe: } \\
1173 \\
\text { Severe: } 306\end{array}$ & $\begin{array}{l}\text { Non-severe: } 166 \\
\text { (14\%) vs. Severe: } \\
87(28.4 \%) ; \\
\text { p <0.0001* }\end{array}$ & $\begin{array}{l}\text { Non-severe: } 72 \\
\text { (6\%) vs. Severe: } \\
53(17.3 \%) \\
\text { p < } 0.0001^{*}\end{array}$ & $\begin{array}{l}\text { Non-severe: } 34 \\
\text { (2.9\%) vs. Severe: } \\
27(8.8 \%) \\
\text { p <0.0001 }\end{array}$ & - \\
\hline
\end{tabular}

ICU: Patients requiring Intensive Care Unit; Non-ICU: Patients not requiring intensive care unit; BP: Blood Pressure; Sys BP: Systolic blood pressure; MAP: Mean arterial pressure; ARDS: Patients with acute respiratory distress syndrome; Non-ARDS: Patients without acute respiratory distress syndrome. ${ }^{*} \mathrm{p}<0.001$.

veloped as an experimental drug (APN01, GSK2586881) for adult respiratory distress syndrome (ARDS) and is therefore available for clinical trials. It was shown that ACE-2 could successfully prevent lung injury by the original SARS-Cov-2 [16]. For ARDS, it had favorable effects in mice and piglets, but the results from a recent study in humans has been disappointing [35-39].

Another crucial step in cellular infection involves the serine protease TMPRSS2 that cleaves the viral S-protein. The TMPRSS2 inhibitor camostat mesylate has been approved in Japan for pancre- atic inflammation and has been shown to prevent cellular infection by SARS-Cov-2 [14]. Consequently, it could prove being useful in Covid-19.

Both $\mathrm{ACE}$ inhibitors and $\mathrm{AT}_{1}$ receptor blockers have been used in diabetes and cardiovascular disorders to modulate this system in preference for vasodilation and maintenance of endothelial integrity. Furthermore, in the diabetic kidney, reduced ACE-2 protein expression could be prevented by ACE inhibitor therapy suggestive of an upregulation with ACE inhibitor [19]. It is worthwhile men- 
tioning that ACE-2 receptor upregulation due to angiotensin receptor blockers that are commonly used in hypertension could be considered to be risk factor for increased transmission of SARS-Cov-2 . However, it has been seen that the $\mathrm{AT}_{1}$ receptors tends to associate with ACE- 2 in these cases, which prevent the internalization of the $A C E-2$ receptor and hence may not be amenable to viral entry [40]. Moreover, as mentioned earlier, higher expression of ACE-2 was not associated with higher susceptibility to infection with SARS-CoV.

\section{Clinical implications}

According to the scientific data detailed above, it is tempting to speculate that blocking the ACE-Ang II-AT $T_{1}$ receptor axis with $\mathrm{AT}_{1}$ blockers commonly used as antihypertensives may tilt the balance in favor of the ACE-2-Ang-(1-7)-Mas axis, which may help to accelerate respiratory recovery in patients suffering from COVID-19 [41]. However, it is intriguing that the patients most likely to be treated with ACE-I or $\mathrm{AT}_{1}$ blockers are the ones with the poorest prognosis in COVID-19 [1-7]. Moreover, ACE-2 upregulation concomitant with RAS inhibitions may ease viral infection. Consequently, it is also possible, that RAS blockade may have a detrimental effect in COVID-19. Currently, there is no clinical data to support one or the other direction. Thus, the Heart Failure Society of America, the American College of Cardiology, and the American Heart Association have all issued statement to suggest that there is no definitive evidence of harm or benefit with the use of ACE-inhibitors or $\mathrm{AT}_{1}$ receptor blockers and that patients should continue to take their medications as usual [42]. It is of the utmost priority to evaluate the growing stock of clinical data from China and worldwide to determine if RAS inhibitors are beneficial or deleterious in COVID-19. Only then, we can know how to counsel our patients taking RAS inhibitors . In fact some researchers are planning a clinical trial to study losartan in COVID-19 patients [43].

\section{Conclusion}

Individuals with underlying hypertension, type 2 diabetes, or cardiovascular disease are at higher risk for respiratory failure and mortality in COVID-19. One of possible mechanisms for this predilection may be the imbalance in the ACE pathways and therapeutics targeting viral entry through the ACE-2 receptor or the ACE-Ang II$\mathrm{AT}_{1}$ receptor axis as well as stimulating the ACE-2-Ang-(1-7)-Mas axis may be beneficial in these individuals. Further evidence needs to be gathered on whether modulation of the renin angiotensin system would be advantageous due to upregulation of Mas activation or harmful due to the concomitant ACE-2 receptor upregulation in the acute management of COVID-19.

\section{Funding}

RD is supported by Ministry of Health, Clinician Scientist Award [MOH-CSAINV17nov-0006]; and National Medical Research Council Centre Grant [NMRC/CG/017/2013]. BOB is supported by Ong Tiong Tat Professorship.

\section{Conflict of Interest}

The authors declare that they have no conflict of interest.

\section{References}

[1] Special Expert Group for Control of the Epidemic of Novel Coronavirus Pneumonia of the Chinese Preventive Medicine Association [An update on the epidemiological characteristics of novel coronavirus pneumonia COVID-19]. Zhonghua Liu Xing Bing Xue Za Zhi 2020; 41: 139-144

[2] Korean Society of Infectious Diseases, Korean Society of Pediatric Infectious Diseases, Korean Society of Epidemiology, Korean Society for Antimicrobial Therapy, Korean Society for Healthcare-associated Infection Control and Prevention, Korea Centers for Disease Control and Prevention. Report on the Epidemiological Features of Coronavirus Disease 2019 (COVID-19) Outbreak in the Republic of Korea from January 19 to March 2, 2020. J Korean Med Sci 2020; 35: e112

[3] Zhou F, Yu T, Du R et al. Clinical course and risk factors for mortality of adult inpatients with COVID-19 in Wuhan, China: A retrospective cohort study. Lancet. 2020; doi:10.1016/S0140-6736(20)30566-3 [Epub ahead of print]

[4] Huang C, Wang Y, Li X et al. Clinical features of patients infected with 2019 novel coronavirus in Wuhan, China. Lancet 2020; 395: 497-506

[5] Wang D, Hu B, Hu C et al. Clinical characteristics of 138 hospitalized patients with 2019 novel coronavirus-infected pneumonia in Wuhan, China. JAMA 2020; doi:10.1001/jama.2020.1585 [Epub ahead of print]

[6] Guan W], Ni ZY, Hu Y et al. For the China Medical Treatment Expert Group for COVID-19. Clinical Characteristics of Coronavirus Disease 2019 in China. N Engl ] Med 2020; doi:10.1056/NE]Moa2002032 [Epub ahead of print]

[7] Wu C, Chen X, Cai Y et al. Risk Factors Associated With Acute Respiratory Distress Syndrome and Death in Patients With Coronavirus Disease 2019 Pneumonia in Wuhan, China. JAMA Intern M. Ed. 2020; doi:10.1001/jamainternmed.2020.0994 [Epub ahead of print]

[8] Bornstein SR, Dalan R, Hopkins D et al. Endocrine and metabolic link to coronavirus infection. Nat Rev Endocrinol 2020; doi:10.1038/ s41574-020-0353-9

[9] Yan R, Zhang Y, Li Y et al. Structural basis for the recognition of the SARS-Cov-2 by full length human ACE-2. Science. 2020; doi:10.1126/ science.abb2762 [Epub ahead of print]

[10] Zhang H, Penninger JM, Li Y et al. Angiotensin-converting enzyme 2 (ACE2) as a SARS-CoV-2 receptor: molecular mechanisms and potential therapeutic target. Intensive Care Med. 2020 doi:10.1007/ s00134-020-05985-9 [Epub ahead of print]

[11] Donoghue M, Hsieh F, Baronas E et al. A novel angiotensin-converting enzyme-related carboxypeptidase (ACE2) converts angiotensin I to angiotensin 1-9. Circ Res 2000; 87: E1-E9

[12] Hamming I, Timens W, Bulthuis ML et al. Tissue distribution of ACE2 protein, the functional receptor for SARS coronavirus. A first step in understanding SARS pathogenesis. J Pathol 2004; 203: 631-637

[13] Lukassen S, Chua RL, Trefzer T et al. SARS-CoV-2 receptor ACE2 and TMPRSS2 are predominantly expressed in a transient secretory cell type in subsegmental bronchial branches (preprint); bioRxiv. 2020; doi:10.1101/2020.03.13.991455

[14] Hoffmann M, Kleine-Weber H, Schroeder S et al. SARS-CoV-2 Cell Entry Depends on ACE2 and TMPRSS2 and Is Blocked by a Clinically Proven Protease Inhibitor. Cell. 2020; doi:10.1016/j.cell.2020.02.05

[15] Jia HP, Look DC, Shi L et al. ACE2 receptor expression and severe acute respiratory syndrome coronavirus infection depend on differentiation of human airway epithelia. J Virol 2005; 79: 14614-14621 
[16] Kuba KY, Imai S, Rao H et al. A crucial role of angiotensin converting enzyme 2(ACE2) in SARS coronavirus-induced lung injury. Nat Med 2005; 11: 875-879

[17] Lambert DW, Hooper NM. Turner. Angiotensin-converting enzyme 2 and new insights into the renin-angiotensin system. AJ Biochem Pharmacol 2008; 75: 781-786

[18] Ribeiro-Oliveira A Jr., Nogueira Al, Pereira RM et al. The renin-angiotensin system and diabetes: An update. Vasc Health Risk Manag 2008; 4: 787-803

[19] Tikellis C, Thomas MC. Angiotensin-converting enzyme (ACE2) is a key modulator of the renin angiotensin system in health and disease. Int J Pept 2012; 256294:256294.doi:10.1155/2012/256294

[20] Simões e Silva AC, Silveira KD, Ferreira A] et al. ACE2, angiotensin-(1-7) and Mas receptor axis in inflammation and fibrosis. $\mathrm{Br}$ J Pharmacol 2013; 169: 477-492

[21] Song J, Hu B, Qu H et al. Upregulation of angiotensin converting enzyme 2 by shear stress reduced inflammation and proliferation in vascular endothelial cells. Biochem Biophys Res Commun 2020; doi:10.1016/j.bbrc.2020.02.151

[22] Peters ]. Peptides. Local renin-angiotensin systems in the adrenal gland. Peptides 2012; 34: 427-432

[23] Nakayama T, Izumi Y, Soma M et al. Adrenal renin-angiotensin-aldosterone system in streptozotocin-diabetic rats. Horm Metab Res 1998; 30: $12-15$

[24] Sadik NA, Metwally NS, Shaker OG et al. Local renin-angiotensin system regulates the differentiation of mesenchymal stem cells into insulin -producing cells through angiotensin type 2 receptor. Biochimie 2017; 137: 132-138

[25] Henricksen E], Prasannarong M. The role of the renin-angiotensin system in the development of insulin resistance in skeletal muscle. Mol Cell Endocrinol 2013; 378: 15-22

[26] Kawabe $\mathrm{Y}$, Mori J, Morimoto $\mathrm{H}$ et al. ACE2 exerts anti-obesity effect via stimulating brown adipose tissue and induction of browning in white adipose tissue. Am J Physiol Endocrinol Metab. 2019; 317: E1140E1149

[27] Yang JK, Lin SS, Ji XJ et al. Binding of SARS coronavirus to its receptor damages islets and causes acute diabetes. Acta Diabetol 2010; 47: 193-199

[28] Hosseiny M, Kooraki S. Ali Gholamrezanezhad et al. Radiology perspective of coronavirus disease 2019 (COVID-19): Lessons from severe acute respiratory syndrome and middle east respiratory syndrome. Am J Roentgenol 2020; 1-5. doi:10.2214/AJR.20.22969; https://www.ajronline.org/doi/full/10.2214/AJR.20.22969

[29] Tian S, Hu W, Niu L et al. Pulmonary pathology of early-phase 2019 novel coronavirus (COVID-19) Pneumonia in two patients with Lung Cancer. J Thor Surg 2020; doi:10.1016/j.jtho.2020.02.010 [Epub ahead of print]
[30] Chinese Clinical Guidance for COVID-19 Pneumonia Diagnosis and Treatment (7th edition) http://kjfy.meetingchina.org/msite/news/ show/cn/3337.html; Accessed 21st March 2020

[31] Xu Z, Shi L, Wang Y et al. Pathological findings of COVID-19 associated with acute respiratory distress syndrome. Lancet Respir Me d 2020; doi:10.1016/S2213-2600(20)30076-X [Epub ahead of print]

[32] Thevarajan I, Nguyen THO, Koutsakos M et al. Breadth of concomitant immune responses prior to patient recovery: A case report of non-severe COVID-19. Nat Med 2020; doi:10.1038/s41591-020-0819-2

[33] Dong C Jr., Xiaokuni L, Qifa S Sr. et al. Hypokalemia and clinical implications in patients with coronavirus disease 2019 (COVID-19). doi:10.1101/2020.02.27.20028530

[34] Chen J, Jiang Q, Xia X et al. Individual variation of the SARS-CoV2 receptor ACE2 gene expression and regulation. Preprints 2020; 2020030191

[35] Casadevall A, Pirofski LA. The convalescent sera option for containing COVID-19. J Clin Invest 2020; doi:https://doi.org/10.1172/JCl138003

[36] Imai Y, Kuba K, Rao $S$ et al. ACE-2 protects from severe acute lung failure. Nature 2005; 436: 112-116

[37] Zhang R, Pan Y, Fanelli V et al. Mechanical stress and the induction of lung fibrosis via the midkine signalling pathway. Am J Respir Crit Care Med 2015; 192: 315-323

[38] Wosten-van Asperen RM, Lutter R, Specht PA et al. Acute respiratory distress syndrome leads to reduced ratio of ACE/ACE- 2 activities and is prevented by Ang-(1-7) or an Ang II receptor antagonists. J Pathol 2011; 225: 618-627

[39] Khan A, Benthim C, Zeno B et al. A pilot clinical trial of recombinant human angiotensin-converting enzyme 2 in acute respiratory distress syndrome. Crit Care 2017; 21: 234

[40] Deshotels MR, Xia H, Sriramula S et al. Angiotensin II mediates angiotensin converting enzyme type 2 internalization and degradation through an angiotensin II receptor type 1 receptor-dependent mechanism. Hypertension 2014; 64: 1368-1375

[41] Sun ML, Yang JM, Sun YP et al. [Inhibitors of RAS Might Be a Good Choice for the Therapy of COVID-19 Pneumonia]. Zhonghua Jie He He Hu Xi Za Zhi 2020; 43: E014 doi:10.3760/ cma.j.issn.1001-0939.2020.0014

[42] Bozkurt B, Kovacs R, Harrington B. HFSA/ACC/AHA statement addresses concerns re: using RAAS antagonists in COVID-19. Published and accessed on: March 172020

[43] http://www.startribune.com/university-of-minnesota-to-test-threedrugs-for-covid-patients/568766632/; Accessed 21st March 2020 